\title{
KLIJANJE I DORMANTNOST KOD MAHUNARKI
}

\author{
GERMINATION AND DORMANCY OF LEGUMES
}

\section{Saraf, Monika Vidak, Martina Grdiša, Klaudija Carović-Stanko}

\section{SAŽETAK}

Mahunarke su glavni izvor biljnih bjelančevina u svijetu stoga zauzimaju važnu ulogu u prehrani ljudi i hranidbi životinja. U Hrvatskoj se zrnate mahunarke pretežno uzgajaju na obiteljskim gospodarstvima na malim površinama. Za ljudsku prehranu najviše se uzgajaju grah (Phaseolus vulgaris L.), grašak (Pisum sativum L.) i soja (Glycine max L. Merr.), a u manjoj mjeri bob (Vicia faba L.), slanutak (Cicer arietinum L.), leća (Lens culinaris Medik.), sjekirica (Lathyrus sativus L.), lupina (Lupinus spp.) i crnookica (Vigna unguiculata L.). Najvažnije krmne mahunarke su lucerna (Medicago sativa L.) i crvena djetelina (Trifolium pratense L.).

Klijanje i dormantnost su složeni procesi sjemena biljaka koji su pod utjecajem gena, biljnih hormona i okolišnih čimbenika. Klijanje je osnovna karakteristika svakog zdravog sjemena i ono počinje kada su zadovoljeni određeni uvjeti (voda, temperatura, kisik, svjetlost $\mathrm{i}$ dr.) te je savladana dormantnost. Mahunarkama je svojstvena fizikalna dormantnost koja je uzrokovana tvrdom, nepropusnom sjemenom ljuskom, koja onemogućuje usvajanje vode i plinova. Kod modernih kultivara zrnatih mahunarki ovo je svojstvo izgubljeno tijekom procesa udomaćenja i oplemenjivanja. Danas je dormantnost tipična za divlje tipove zrnatih mahunarki i za krmne mahunarke, kod kojih je potrebno primijeniti metode skarifikacije ili stratifikacije kako bi se prekinula dormantnost te potaknulo i poboljšalo klijanje.

Ključne riječi: dormantnost, klijanje, krmne mahunarke, tvrda sjemena ljuska, zrnate mahunarke

\section{ABSTRACT}

Legumes are of great importance in human nutrition and animal feed as they are a major source of vegetable proteins. In Croatia, grain legumes are mainly grown on family farms in low-system production. Common bean (Phaseolus vulgaris L.), pea (Pisum sativum L.) and soybean (Glycine max L. Merr.) are the 
most widely grown while broad bean (Vicia faba L.), chickpea (Cicer arietinum L.), lentil (Lens culinaris Medik.), grass pea (Lathyrus sativus L.), lupin (Lupinus spp.) and cowpea (Vigna unguiculata L.) are grown to a lesser extent. The most common forage legumes in Croatia are alfalfa (Medicago sativa L.) and red clover (Trifolium pratense L.).

Germination and dormancy are complex seed characteristics influenced by many genes, hormones and environmental factors. Germination of the healthy seed starts when all the environmental factors are satisfied (water, temperature, oxygen, light, etc.), and it has overcome primary dormancy. Physical dormancy is widespread in legume family and is caused by an impermeable seed coat for water and gases, but has been lost through domestication and breeding. Today, physical dormancy is typical for wild types of grain legumes and for forage legumes. Stratification and scarification methods are useful tools to break down dormancy and improve germination.

Keywords: forage legumes, grain legumes, hard seed coat, seed dormancy, seed germination

\section{UVOD}

Mahunarke (Leguminosae, Fabacae) su ključni elementi globalne poljoprivrede i prehrane, kako za ljude, tako i za životinje, budući da su glavni izvor biljnih bjelančevina (De Ron, 2015.). Na temelju ukupne proizvodnje, ova porodica je druga po važnosti u svijetu (Morel i sur., 2012.). Zrnate mahunarke su važan izvor bjelančevina osobito u zemljama u kojima su životinjske bjelančevine nedostupne ili se ne konzumiraju iz vjerskih ili kulturoloških razloga. Osim bjelančevina, dobar su izvor sporo razgradivih ugljikohidrata, vlakana, minerala, vitamina i fitotvari te ih se smatra funkcionalnom hranom (Boye i sur., 2010.). Krmne mahunarke iz rodova djeteline (Trifolium) i lucerne (Medicago) imaju ključnu ulogu u održivim sustavima proizvodnje krme umjerenih područja. U ishrani stoke su vrlo važne zbog visokog sadržaja bjelančevina, koje imaju vrlo povoljan aminokiselinski sastava, te zbog visokog sadržaja vitamina i minerala (Leto, 2013.). Mahunarke su također važan čimbenik u prirodnom ciklusu dušika te su osobito korisne u poljoprivredi zbog poboljšanja plodnosti tla vezanjem atmosferskog dušika (De Ron, 2015.).

Klijanje i dormantnost su složeni procesi u sjemenu koje kontrolira veliki broje gena i biljnih hormona (Koornneef, 2002.), a isto tako ih na vrlo složen način kontrolira jedan ili više morfoloških, fizioloških i/ili fizičkih čimbenika (Fuller i Allaby, 2009.). Utvrđeno je da sjeme postaje dormantno tijekom 
procesa sazrijevanja (primarna dormantnost), a dormantnost je povezana $\mathrm{s}$ dehidracijom, koja se odvija tijekom posljednjih faza sazrijevanja sjemena (Gubler i sur., 2005.; Gresta i sur., 2011.). Hoće li se dormantnost u zrelom sjemenu održati ovisi o okolišnim i genetskim čimbenicima (Gubler i sur., 2005.). Dormantno sjeme ne klije u uvjetima koji su povoljni za klijanje (Baskin i Baskin, 2004.), a dormantnost predstavlja prilagodbu biljaka koja onemogućuje klijanje sjemena nakon sazrijevanja, što je u mnogim klimatskim uvjetima poželjno svojstvo (Bewley, 1997.) kako ne bi došlo do priježetvenog klijanje i velikih gubitaka (Gubler i sur., 2005.).

Kod zrnatih mahunarki, kod kojih je udomaćenjem kroz oplemenjivanje došlo do gubitka dormantnosti, klijanje je uglavnom pod kontrolom dostupnosti vode i temperature tla, ali je utjecaj okolišnih čimbenike jako povezan $\mathrm{s}$ taksonomskom pripadnošću i klimatskim područjem podrijetla mahunarke (Kigel i sur., 2015.). Iako je dormantnost, uzrokovana tvrdom sjemenom ljuskom, jedan od glavnih problema vezanih uz proizvodnju krmnih mahunarki (Kimura i Islam, 2012.), dormantnost sjemena je od ekološke važnosti jer može produžiti životni vijek sjemena te ima veliki učinak na opstanak vrste u prirodi.

\section{Proizvodnja mahunarki u Republici Hrvatskoj}

Duga tradicija uzgoja mahunarki u Hrvatskoj omogućila je razvoj mnogih tradicijskih kultivara prilagođenih specifičnoj klimatskoj i reljefnoj raznolikosti Hrvatske (Čupić i sur., 2012.). Zrnate mahunarke koje se uzgajaju u Hrvatskoj na obiteljskim gospodarstvima su grah (Phaseolus vulgaris L.), grašak (Pisum sativum L.) i soja (Glycine max L. Merr.). Rjeđe, najčešće na prostoru Dalmacije, uzgajaju se bob (Vicia faba L.), slanutak (Cicer arietinum L.), leća (Lens culinaris Medik.), sjekirica (Lathyrus sativus L.), lupina (Lupinus spp.) i crnookica (Vigna unguiculata L.). Najveća raznolikost jednogodišnjih mahunarki u Hrvatskoj utvrđena je u Dalmaciji, a najmanja u Istri te se najčešće uzgajaju za ljudsku prehranu, manje kao stočna hrana, a sjekirica i za ispašu pčela (Čupić i sur., 2012.). Lucerna (Medicago sativa L.) se smatra najvažnijom krmnom kulturom (Leto, 2013.), dok je crvena djetelina (Trifolium pratense L.), odmah nakon lucerne, najvažnija višegodišnja krmna mahunarka prema rasprostranjenosti i značajnosti u proizvodnji voluminozne stočne krme (Dujmović-Purgar i sur., 2009.).

Grah je u Hrvatskoj zapostavljena kultura koja se uzgaja na tradicionalan način na malim obiteljskim gospodarstvima. No, u odnosu na druge mahunarke najrasprostranjenija je vrsta u Hrvatskoj za ljudsku prehranu (Čupić i sur., 2012.). U Hrvatskoj je u 2015. godini zabilježena proizvodnja graha za svježe i 
suho zrno te mahune na površini od oko 2000 ha (Statistički ljetopis Republike Hrvatske, 2016.), a najviše se uzgaja u sjevernim djelovima Hrvatske.

U Hrvatskoj se za tržište u 2015. godini grašak za svježe zrno i mahune proizvodio na obiteljskim gospodarstvima na oko 600 ha (Statistički ljetopis Republike Hrvatske, 2016.). Čupić i sur. (2012.) su utvrdili da se u Hrvatskoj stare sorte, lokalne populacije i poludivlje forme graška koriste za hranidbu stoke.

Soja obiluje bjelančevinama i drugim nutrijentima te se u Hrvatskoj najčešće koristi za hranidbu stoke i kao industrijska kultura, dok se u ljudskoj prehrani manje koristi, a nema ni kapaciteta za preradu (Ranogajec i sur., 2014.). Soja se 2015. godine u Hrvatskoj proizvodila na nešto više od 88000 ha (Statistički ljetopis Republike Hrvatske, 2016.).

Bob se u Hrvatskoj uzgaja pretežno u Dalmaciji za ljudsku prehranu (Čupić i sur., 2012.). Uzgajaju se tradicijski kultivari iz vlastito proizvedenog sjemena u vrtovima za osobne potrebe, manji dio se prodaje na tržnicama, a u mladim maslinicima i voćnjacima se uzgaja i kao podusjev (Čupić i sur., 2012.; Ozimec i sur., 2015.). Nije poznato na kolikim se površinama uzgaja.

Zbog otpornosti na sušu slanutak se za ljudsku prehranu u Hrvatskoj najviše uzgaja u primorskim krajevima, Dalmaciji i Istri, ali ga se može pronaći i u kontinentalnim krajevima (Čupić i sur., 2012.; Ozimec i sur., 2015.). Domaći sitnozrni slanutak se uzgaja kao ratarska kultura, a krupnozrni kao povrtnica, ali su sve manje prisutni u proizvodnji te površine zasijane slanutkom nisu poznate (Ozimec i sur., 2015.). Uzgajaju se tradicijski kultivari iz vlastito proizvedenog sjemena (Čupić i sur., 2012.; Ozimec i sur., 2015.).

U Hrvatskoj se leća uzgaja za ljudsku prehranu samo na obiteljskim gospodarstvima na području Dalmacije (Čupić i sur., 2012.; Ozimec i sur., 2015.). Iako je poznata po prilagodbi na loše uvjete tla i tolerantna je na sušu, populacija domaće leće je gotovo nestala te joj prijeti izumiranje (Ozimec i sur., 2015.).

Sjekirica se u Hrvatskoj proizvodi na malim površinama na uskom području sjeverne i južne Dalmacije, najviše u zaleđu Zadra i okolici Dubrovnika. Procjenjuje se da se uzgaja na svega 10 ha s blagim trendom povećanja, a uzgajaju se tradicijski kultivari te divlje i poludivlje forme iz vlastito proizvedenog sjemena (Čupić i sur., 2012.; Ozimec i sur., 2015.).

Podaci o površinama koje su zasijane lupinom i crnookicom u Hrvatskoj nisu poznati. Rijetko se uzgajaju (Lešić i sur., 2004.; Ozimec i sur., 2015.), ali 
se u sušnim dijelovima Dalmacije i na otocima mogu pronaći tradicijski kultivari ovih kultura (Čupić i sur., 2012.), gdje zbog visokih temperatura grah zrnaš daje niske prinose (Lešić i sur., 2004.).

Lucerna zauzima vodeće mjesto među krmnim mahunarkama te se u 2015. godini za sijeno proizvodila na površini od 18386 ha (Statistički ljetopis Republike Hrvatske, 2016.). Koristi se prvenstveno za košnju, u monokulturi ili u smjesi s drugim mahunarkama i travama, ali su razvijeni i kultivari tolerantni na napasivanje (Leto, 2013.).

U Hrvatskoj postoji 76 vrsta djetelina (Dujmović-Purgar i sur., 2009.) koje su se u 2015. godini proizvodile za sijeno na 9549 ha (Statistički ljetopis Republike Hrvatske, 2016.). Crvena djetelina se uzgaja u svim regijama Hrvatske kao ratarska kultura, kao čisti usjev ili u smjesi s travama za proizvodnju kvalitetnog sijena, za ishranu stoke u zelenom stanju, za zelenu gnojidbu, silažu te se koristi kao medonosna i ljekovita biljka (Dujmović-Purgar i sur., 2009.).

\section{ČIMBENICI KOJI UTJEČU NA KLIJANJE MAHUNARKI}

Kako bi proces klijanja započeo, sjeme mora biti klijavo, trebaju biti zadovoljeni odgovarajući ekološki čimbenici te treba biti savladana primarna dormantnost (Hartmann i sur., 1990.). U ekološke čimbenike potrebne za klijanje ubrajaju se voda, temperatura, kisik, svjetlost, $\mathrm{pH}$ tha te stupanj zaslanjenosti tla (Okçu i sur., 2005.; Finch-Savage i Leubner-Metzger, 2006.; Cokkizgin, 2012.). Proces klijanja sjemena odvija se u četiri faze: usvajanje vode (imbibicija), formiranje (aktiviranje) enzimskih sustava, početak razvoja klijanaca te daljnji rast i razvoj klijanaca (ISTA, 2006).

Kod dvosupnica je poznato epigejsko i hipogejsko klijanje. Kod epigejskog klijanja supke probijaju sjemenu ljusku, izlaze iznad površine zemlje, ozelene te kraće ili dulje vrijeme asimiliraju kao pravi listovi (grah, soja, lupina, crnookica). Kod hipogejskog klijanja supke ostaju trajno obavijene sjemenom ljuskom i skrivene pod zemljom te služe kao spremište rezervnih tvari (bob, leća, grašak, slanutak, sjekirica) (Jevtić i sur., 1986.; Black i sur., 2006.; Chaturvedi i sur., 2011.).

Kakvoća sjemena

Poznato je da kakvoća sjemena utječe na klijanje, a time i na uspostavu održivog i profitabilnog usjeva (Finch-Savage i Bassel, 2015.). Klijavost sjemena je jedna od važnijih sastavnica kakvoće sjemena (Van Gastel i sur., 
2007.) koja se utvrđuje standardnom metodom ispitivanja klijavosti ISTA-e. Test ispitivanja klijavosti je standardiziran, ponovljiv i vrijedan pokazatelj kvalitete sjemena (ISTA, 2009). Na kakvoću sjemena utječu agroekološki uvjeti tijekom vegetacije, proces dorade te uvjeti skladištenja sjemena, a čine je genetska, fizikalna, fiziološka i zdravstvena svojstva te uniformnost partije sjemena (Van Gastel i sur., 2007.). Dakle, klijavost sjemena ovisi o velikom broju čimbenika kao što su temperatura prilikom klijanja, temperatura i vlaga zraka tijekom skladištenja sjemena, vlaga zrna, dužina skladištenja, odnosno, starost sjemena te njegova veličina (Bukvić i sur., 2009.). Zbroj svih osobina sjemena koje određuju razinu aktivnosti i svojstva sjemena ili partije sjemena tijekom klijanja i nicanja u različitim okolišnim uvjetima naziva se vigor (ISTA, 2009). Vigor sjemena se odražava na sposobnost klijanja sjemena u različitim okolišnim uvjetima, na početni porast biljke i ujednačenost usjeva (FinchSavage i Bassel, 2015.).

Ellis i Hong (2006.) su ispitivali vigor sjemena crvene djeteline i lucerne koje je hermetički čuvano 14,5 godina pri različitoj vlazi (2-15\%) i različitim temperaturama $\left(-20,30,40,50\right.$ i $\left.65{ }^{\circ} \mathrm{C}\right)$. Sjeme crvene djeteline je sačuvalo životnu sposobnost na temperaturi od $-20{ }^{\circ} \mathrm{C}$ pri sadržaju vlage $2,2-14,9 \%$, a sjeme lucerne pri vlazi $2-12 \%$. Negativna povezanost životne sposobnosti sjemena i sadržaja vlage $(4,0-5,4 \%$ za crvenu djetelinu i $4,2-5,5 \%$ za lucernu) dobivene su pri temperaturama čuvanja od 30 do $65^{\circ} \mathrm{C}$. Bukvić i sur. (2007.) su kod soje i krmnog graška utvrdili da je postotak klijavosti sjemena niži što je sjeme starije.

Veličina sjemena

Veličina sjemena utječe na klijanje i energiju klijanja mahunarki. Općenito, kod graha, leće i slanutka krupnije sjeme ima bolju klijavost, brže niče te daje otpornije i veće klijance u usporedbi sa sitnijim sjemenom, a kod soje sitno sjeme daje manje prinose od onog srednje i krupne frakcije (Ambika i sur., 2014.).

Haramija (2007.) je utvrdio statistički značajnu vezu između krupnoće i energije klijanja sjemena graha mahunara. Najveća energija klijanja i klijavost utvrđena je kod srednje frakcije, dok je najmanja energija klijanja i klijavost utvrđena kod krupne frakcije sjemena. Autor je zaključio da krupnija frakcija sjemena graha mahunara ima specifičnu građu sjemena, u žetvi i doradi dolazi do mehaničkog oštećenja sjemena te je moguće da takvo sjeme ima manju energiju klijanja i klijavost. Sinck i sur. (2004.) su kod različitih genotipova graška utvrdili pozitivnu korelaciju težine sjemena $\mathrm{s}$ rastom biljaka pri 
različitim temperaturama $\left(2,5,10\right.$ i $\left.20^{\circ} \mathrm{C}\right)$. Al-Karaki (1998.) je utvrdio da krupnije sjeme leće bolje upija vodu od sjemena srednje veličine ili sitnog sjemena te samim time i brže klije.

Voda

Dostupnost vode je osnovni preduvjet za početak procesa klijanja koje započinje njenim usvajanjem. Suho sjeme brzo upija vodu (faza I) sve dok stanice nisu u potpunosti hidratizirane, potom slijedi razdoblje ograničenog unosa vode (faza II - faza platoa), dok se daljnje povećanje unosa vode (faza III) odnosi na završetak nicanja i izlazak klice na površinu (Nonogaki, 2010.).

Proces klijanja mahunarki započinje kad sjeme upije određenu količinu vode u odnosu na masu sjemena, npr.: grah $75-110 \%$, soja $110-150 \%$, grašak oko $115 \%$, leća $100-110 \%$, slanutak $90-100 \%$ (Jevtić i sur., 1986.), lucerna 125\% (Undersander i sur., 2011.). Kod većih količina tanina u grahu usvajanje vode je slabije, dok je kod manjih količina fenola, tanina, i nezasićenih masnih kiselina usvajanje vode jače (Kigel i sur., 2015.). Debljina sjemene ljuske može biti limitirajući čimbenik za usvajanje vode. Noodén i sur. (1985.) su utvrdili da tijekom sušnog razdoblja sjemena ljuska soje postane deblja, a time i nepropusna za vodu te tada dolazi do odgode klijanja i u pogodnim uvjetima za klijanje (Fenner i Thompson, 2005.). Kod krmnih mahunarki je tvrda sjemena ljuska nepropusna za vodu i plinove te ju je potrebno skarificirati ili je potrebno stratificirati sjeme (Kimura i Islam, 2012.).

\section{Temperatura}

Sve reakcije i faze u procesu klijanja pod utjecajem su temperature. Za proces klijanja sjemena važna su tri osnovna temperaturna praga: temperaturni minimum (ispod kojeg ne dolazi do procesa klijanja), temperaturni optimum (najveći postotak klijanja u najkraćem vremenu) i temperaturni maksimum (iznad kojeg se klijanje prekida) (Shaban, 2013.), a ovise o vrsti, dormantnosti sjemena i dr. (Machado Neto i sur., 2006.). Temperatura ima i indirektan utjecaj na klijanje sjemena s obzirom da je kod pojedinih biljnih vrsta odgovarajuća temperatura neophodna za prekid dormantnosti (Black i sur., 2006.).

Klijanje sjemena se u agroekološkim uvjetima Hrvatske odvija pri različitim temperaturama jer se sjetva može obavljati u proljetnom i jesenskom roku.

Minimalne i optimalne temperature potrebne za klijanje pojedine mahunarke prikazane su u Tablici 1. 
D. Saraf i sur.: Klijanje i dormantnost kod mahunarki

Tablica 1. Minimalne i optimalne temperature potrebne za klijanje pojedine mahunarke

Table1 Minimum and optimal temperatures required for seed germination of some legumes

\begin{tabular}{|c|c|c|c|c|}
\hline & $\begin{array}{l}\text { Kultura } \\
\text { (Species) }\end{array}$ & $\begin{array}{c}\text { Minimalna } \\
\text { temperatura } \\
\text { (Minimum } \\
\text { temperatures) } \\
\left({ }^{0} \mathrm{C}\right)\end{array}$ & $\begin{array}{l}\text { Optimalana } \\
\text { temperatura } \\
\text { (Optimal } \\
\text { temperatures) } \\
\left({ }^{\circ} \mathrm{C}\right)\end{array}$ & $\begin{array}{c}\text { Izvor } \\
\text { (Source) }\end{array}$ \\
\hline \multicolumn{2}{|c|}{$\begin{array}{l}\text { Grah, common bean } \\
\text { (Phaseolus vulgaris L.) }\end{array}$} & $8-10$ & $18-22$ & $\begin{array}{l}\text { Lešić i sur., 2004 } \\
\text { (Lešić et al. 2004) }\end{array}$ \\
\hline \multirow{2}{*}{$\begin{array}{l}\text { Grašak, pea } \\
\quad \text { (Pisum } \\
\text { sativum L.) }\end{array}$} & $\begin{array}{l}\text { kultivari glatkog } \\
\text { sjemena } \\
\text { (smooth cultivars) }\end{array}$ & 2 & \multirow{2}{*}{20} & \multirow{2}{*}{$\begin{array}{l}\text { Lešić i sur., } 2004 \\
\text { (Lešić et al. 2004) }\end{array}$} \\
\hline & $\begin{array}{c}\text { kultivari naboranog } \\
\text { sjemena } \\
\text { (wrinkled cultivars) }\end{array}$ & $4-5$ & & \\
\hline \multicolumn{2}{|c|}{$\begin{array}{c}\text { Soja, soybean } \\
\text { (Glycine max L. Merr.) }\end{array}$} & $8-10$ & 25 & $\begin{array}{l}\text { Lešić i sur., 2004 } \\
\text { (Lešić et al. 2004) }\end{array}$ \\
\hline \multicolumn{2}{|c|}{$\begin{array}{l}\text { Bob, broad bean } \\
\text { (Vicia faba L.) }\end{array}$} & $1-6$ & 20 & $\begin{array}{l}\text { Lešić i sur., 2004 } \\
\text { (Lešić et al. 2004) }\end{array}$ \\
\hline \multicolumn{2}{|c|}{$\begin{array}{l}\text { Slanutak, chickpea } \\
\text { (Cicer arietinum L.) }\end{array}$} & $5-6$ & 25 & $\begin{array}{l}\text { Lešić i sur., 2004 } \\
\text { (Lešić et al. 2004) }\end{array}$ \\
\hline \multicolumn{2}{|c|}{$\begin{array}{c}\text { Leća, lentil } \\
\text { (Lens culinaris Medik.) }\end{array}$} & 15 & $18-21$ & $\begin{array}{l}\text { Lešić i sur., 2004 } \\
\text { (Lešić et al. 2004) }\end{array}$ \\
\hline \multicolumn{2}{|c|}{$\begin{array}{l}\text { Sjekirica, grass pea } \\
\text { (Lathyrus sativus L.) }\end{array}$} & I & $10-25$ & $\begin{array}{l}\text { Lešić i sur., 2004 } \\
\text { (Lešić et al. 2004) }\end{array}$ \\
\hline \multicolumn{2}{|c|}{$\begin{array}{l}\text { Lupina, lupin } \\
\text { (Lupinus spp.) }\end{array}$} & 1 & $>10$ & $\begin{array}{l}\text { Black i sur., 2006 } \\
\text { (Black et al. 2006) }\end{array}$ \\
\hline \multicolumn{2}{|c|}{$\begin{array}{c}\text { Crnookica, cowpea } \\
\text { (Vigna unguiculata L.) }\end{array}$} & I & 20 & $\begin{array}{l}\text { Lešić i sur., 2004 } \\
\text { (Lešić et al. 2004) }\end{array}$ \\
\hline \multicolumn{2}{|c|}{$\begin{array}{c}\text { Lucerna, alfalfa } \\
\text { (Medicago sativa } \mathrm{L} .)\end{array}$} & 2 & $18-25$ & $\begin{array}{l}\text { Undersander i sur., } \\
2011 \\
\text { (Undersandert et al. } \\
2011 \text { ) }\end{array}$ \\
\hline \multicolumn{2}{|c|}{$\begin{array}{l}\text { Crvena djetelina, red clover } \\
\text { (Trifolium pratense L.) }\end{array}$} & I & $15-20$ & $\begin{array}{l}\text { Brar i sur., 1991 } \\
\text { (Brar et al. 1991) }\end{array}$ \\
\hline
\end{tabular}

Svjetlost

Svjetlost može djelovati na klijanje na tri načina: ili potiče ili sprječava klijanje, dok neke vrste mogu klijati i na svjetlu i u tami (Frankland i Taylorson, 1983.). Može imati direktan utjecaj na klijanje ili na prekid dormantnosti (Black i sur., 2006.). Prema Milberg i sur. (2000.) s povećanjem mase sjemena smanjuje se potreba za svjetlošću prilikom klijanja. 
Svjetlost općenito nema utjecaj na klijanje mahunarki. Međutim, kod osmotskog stresa, svjetlost potiče klijanje graha (Kigel i sur., 2015.).

\section{Koncentracija soli u tlu}

Povećana koncentracija soli je jedan od najvažnijih čimbenika koji odgađa klijanje sjemena, utječe na konačni postotak klijanja te ograničava rast biljaka. Koncentracija soli utječe na klijanje sjemena povećanjem osmotskog potencijala tla, odnosno smanjenjem vodnog potencijala, što otežava ili sprječava apsorpciju vode te dovodi do sprječavanja, odnosno, odgode klijanja (Okçu i sur., 2005.; Cokkizgin, 2012.); ili putem toksičnih učinaka natrijevih i kloridnih iona na proklijalo sjeme, posebice u sušnim područjima (Khajeh-Hosseini i sur., 2003.). Koncentracija $\mathrm{NaCl}$ pri kojoj sjeme ne klije varira između vrsta i kultivara (Khajeh-Hosseini i sur., 2003.).

Cokkizgin (2012.) je ispitivao utjecaj različitih koncentracija $\mathrm{NaCl}(0,0 ; 3,5$; $7,1 ; 10,6 ; 14,2$ i $17,7 \mathrm{~g} / 1)$ na klijanje graha. Utvrdio je da je najveći postotak isklijalih sjemenki graha bio s tretmanom bez $\mathrm{NaCl}$ (kontrola; $0,0 \mathrm{~g} / 1 \mathrm{NaCl}$ ), a najmanji kod najveće razine $\mathrm{NaCl}(17,7 \mathrm{~g} / \mathrm{l})$. Tsegay i Gebreslassie (2014.) su ispitivali utjecaj različitih koncentracija $\mathrm{NaCl}\left(0,5,7,9\right.$ i $\left.15 \mathrm{dSm}^{-}\right)$na klijanje graška i sjekirice. Utvrdili su da se povećanjem razine soli smanjuje postotak klijavosti te duljina klice i korijena kod graška i sjekirice. Kod tretmana bez $\mathrm{NaCl}\left(0 \mathrm{dSm}{ }^{-}\right)$niknuo je najveći broj sjemenki dok kod koncentracije $\mathrm{NaCl}$ od $15 \mathrm{dSm}^{-}$nije bilo proklijalih sjemenki ni kod graška ni kod sjekirice. Također su utvrdili da je grašak manje tolerantan na zaslanjenost nego sjekirica. Kaymakanova (2009.) je utvrdila da je klijanje graha tretiranog $\mathrm{Na}_{2} \mathrm{SO}_{4}$ te $\mathrm{NaCl}$ $\mathrm{u}$ koncentraciji od $100 \mathrm{mM}$ znatno smanjeno u odnosu na kontrolu (netretirano sjeme). Dužina i masa hipokotila i korijena također su znatno niže kod tretiranog sjemena nego kod kontrole. Li i sur. (2010.) su utvrdili da je sjeme lucerne osjetljivo na sol u tlu i tada je klijanje značajno smanjeno.

\section{Kisik}

Potreba za kisikom ovisi o drugim okolišnim čimbenicima: temperaturi, svjetlosti, vodi te o sastavu sjemena (Black i sur., 2006; Bradford i sur., 2007.). Snižavanjem temperature, manja je potreba za kisikom, a sjeme s višim sadržajem masti je osjetljivije na manjak kisika nego sjeme s visokim sadržajem škroba (Bradford i sur., 2007.).

Al-Ani i sur. (1985.) su ispitivali utjecaj kisika na klijavost 12 biljnih vrsta, među kojima su bili soja i grašak. Utvrdili su da se za sve vrste pri $21 \mathrm{kPa} \mathrm{O}$ 
pojavio prvi korijen za 12-24 sata. Maksimalni postotak klijavosti je bio 8095\% za 24-72 sata, ovisno o vrsti. Soja je prestala s klijanjem pri 3 do $1 \mathrm{kPa} \mathrm{O}_{2}$ dok je grašak klijao pri $0,1 \mathrm{kPa} \mathrm{O}_{2}$ što potvrđuje da sjeme s visokim sadržajem škroba klije pri niskim koncentracijama kisika.

$\mathrm{pH}$ vrijednost tla

Nepovoljna pH vrijednost tla je jedan od limitirajućih čimbenika za klijanje (Ghaderi-Far i sur., 2010.).

Iako su za uzgoj soje i graška najpogodnija neutralna tla (za grašak i nešto kiselija), Bukvić i sur. (2007.) su utvrdili da se njihova energija klijanja i klijavost ne mijenjaju značajno ovisno o $\mathrm{pH}$ vodene otopine, ali se dužina korijena i izdanaka značajno mijenjaju. Ispitivali su utjecaj četiriju razina $\mathrm{pH}$ vodene otopine $(5,6,7$ i 8) na klijavost soje i krmnog graška. U prosjeku za sve ispitivane kultivare najveće vrijednosti za dužinu korijena bile su pri $\mathrm{pH} 6$, a za izdanak pri pH 6 i 7. Najmanje vrijednosti za dužinu korijena dobivene su pri pH 7, a za izdanak pri pH 5 i 8. Grljušić i sur. (2007.) su ispitivali utjecaj pH vrijednosti vodene otopine $(5,6,7$ i 8$)$ na svojstva sjemena i klijanaca sorata soje. Utvrđen je značajan utjecaj pH vrijednosti na klijavost, dužinu korijena i hipokotila te masu klijanaca. Klijavost različitih kultivara soje bila je najveća pri pH 5, a najveća dužina korijena i hipokotila pri pH 5 i 6 . Klijavost, dužina korijena i hipokotila te prinos i kakvoća nadzemne mase lucerne značajno ovise o pH reakciji tla (Bukvić i sur., 2008.). Istraživanjem su utvrdili da su, osim energije klijanja, sva ispitivana svojstva sjemena i klijanaca imala više prosječne vrijednosti pri $\mathrm{pH} 4$.

\section{UTJECAJ HORMONA NA KLIJANJE I DORMANTNOST SJEMENA}

Biljni hormoni; apscizinska kiselina (ABA), giberelinska kiselina (GA), auksini (IAA), citokinini, etilen i dr. imaju značajne učinke na razvoj biljaka (Kucera i sur., 2005.). Izuzetno su važni za regulaciju dormantnosti i klijanja sjemena te mogu pozitivno ili negativno utjecati na klijavost sjemena (Koornneef, 2002.; Finkelstein i sur., 2008.; Seo i sur., 2009.; Miransari i Smith, 2014.).

Među najvažnijim parametrima koji kontroliraju proces dormantnosti su promjene na molekularnoj razini, uključujući i modifikacije proteina i hormonalne promjene, osobito ravnotežu između ABA i GA (Miransari i Smith, 2014.). ABA i GA su unutarnji signali koji imaju središnju ulogu u regulaciji 
klijanja sjemena. Utvrđeno je da ABA inhibira klijanje i inducira dormantnost tijekom sazrijevanja klice, a GA stimulira klijanje sjemena kod velikog broja biljnih vrsta (Finkelstein i sur., 2008., Seo i sur., 2009.). S obzirom da ABA i GA u sjemenu kontroliraju dormantnost i klijanje sjemena, više razine ABA-e potiču dormantnost tijekom sazrijevanja klice čime se sprječava priježetveno klijanje (Shu i sur., 2015.). Početak klijanja stimulira povećanje koncentracije GA i/ili citokinina uz pad ABA-e (Eira i Caldas, 2000.).

Interakcije između biljnih hormona i biljnih gena također utječu na klijavost sjemena. Djelovanje biljnih hormona kontrolira ekspresiju gena na različitim razinama, a ujedno se i pojedini biljni geni aktiviraju u prisutnosti određenih biljnih hormona (Miransari i Smith, 2014.).

\section{DORMANTNOST SJEMENA}

Dormantnost ili mirovanje je pojava koja onemogućava prijevremeno klijanje sjemena na samoj biljci, pri kojoj sjeme ne klije ni u povoljnim uvjetima, ali ni u nepogodno doba godine (Bewley, 1997.; Nonogaki, 2014.). Dormantnost sjemena, kao i načini prekida dormantnosti, zajednička je karakteristika mnogim biljnim vrstama. Od izuzetnog je značaja jer omogućava očuvanje sjemena tijekom nepovoljnih vremenskih uvjeta, može produljiti životni vijek sjemena i ima veliki utjecaj na preživljavanje i pojavu biljaka u divljini (Wang i sur., 2007.). Stupanj dormantnosti je nasljedan. Mnogi geni povezani su s dormantnošću, a aktivnost većine gena je povezana s hormonima. Kod mnogih vrsta početak dormantnosti je vezan uz morfološka i fiziološka svojstva sjemena, npr. boja i debljina sjemene ljuske (Black i sur, 2006.).

Nikolaeva (1977.) je dormantnost podijelila na primarnu i sekundarnu. Primarnu dormantnost je još podijelila na endogenu (fiziološka, morfološka i morfo-fiziološka) i egzogenu (fizikalna, kemijska i mehanička) te na sekundarnu. Primarna dormantnost je oblik dormantnosti koji je svojstven tek ubranom sjemenu, a razvija se tijekom sazrijevanja sjemena, dok je sekundarna dormantnost posljedica djelovanja okolišnih čimbenika (Baskin i Baskin, 2004.).

Na temelju podjele koju je dala Nikolaeva, Baskin i Baskin (2004.) su dormantnost podijelili u sljedeće grupe: fiziološka, morfološka, morfofiziološka, fizikalna i kombinirana (fiziološka i fizikalna). 
Fiziološka dormantnost sjemena je najčešći tip dormantnosti, a regulirana je djelovanjem ABA i GA (Kigel i sur., 2015.). Podijeljena je na tri razine: dugotrajna (duboka), prijelazna i kratkotrajna dormantnost.

Sjeme s morfološkom dormantnošću ima malenu (nerazvijenu) klicu (embrij). Takva klica nije fiziološki dormantna i nije joj potreban prekid dormantnosti nego određeno vrijeme da naraste i počne klijati.

Morfo-fiziološka dormantnost se javlja u sjemenu čija klica je nerazvijena, ali sadrži i fiziološke komponente dormantnosti.

Fizikalna dormantnost je uzrokovana nepropusnom (tvrdom) sjemenom ljuskom koja sprječava usvajanje vode i plinova. Sjeme klije tek nakon tretmana za prekid dormantnosti, odnosno nakon mehaničkog ili kemijskog oštećivanja (skarifikacija) sjemene ljuske. Ovaj tip dormantnosti je široko rasprostranjen u porodici mahunarki te se javlja kod divljih predaka kultiviranih mahunarki i jedna je od ključnih osobina koja je izmijenjena udomaćenjem i kroz oplemenjivanje (Kigel i sur., 2015.).

Kombinirana dormantnost (fizikalna i fiziološka) se javlja u sjemenu koje ima i čvrstu sjemenu ljusku te fiziološki dormantnu klicu. Utvrđena je kod mahunarki iz rodova Vicia, Trifolium, Medicago i Lathyrus (Kigel i sur., 2015.).

Dormantnost i prekidi dormantnosti kod mahunarki

Iako je karakteristično svojstvo za mahunarke tvrda, nepropusna sjemena ljuska, koja onemogućava usvajanje vode te ograničava izmjenu plinova, danas je to svojstvo tipično za divlje tipove zrnatih mahunarki, dok je kod modernih kultivara oplemenjivanjem tijekom udomaćivanja došlo do stanjivanja sjemene ljuske (Fuller i Allaby, 2009.). No, tvrda sjemena ljuska i dalje predstavlja glavni problem kod proizvodnje krmnih mahunarki (Kimura i Islam, 2012.).

Prema Smýkal i sur. (2014.) sjemena ljuska mahunarki nema samo strukturnu i zaštitnu funkciju već ima odlučujuću ulogu za početak klijanja s obzirom da regulira primanje vode. Ova uloga je važna pri pojavi promjenjivih okolišnih čimbenika jer osigurava opstanak vrste, pogotovo tijekom dužih sušnih razdoblja (Święcicki i sur., 2015.). Kod zrnatih mahunarki je procesom oplemenjivanja došlo do smanjenja ili gubitaka dormantnosti jer je u proizvodnji bilo potrebno osigurati brzo i ujednačeno klijanje te njihovo sjeme klije odmah nakon sjetve, čim se zadovolje uvjeti za klijanje (Kigel i sur., 2015.). Dormantnost nije izražena kod domaće sjekirice (Gatarić i sur., 2009.), dok se kod boba rijetko javlja, kod graha je došlo do gubitka dormantnosti 
udomaćenjem, a slanutak ima vrlo tanku sjemenu ljusku pa je stoga osjetljiv na mehanička oštećenja. Sjeme svježe požete leće pokazuje dormantnost zbog tvrde sjemene ljuske, ali ona traje 3-4 tjedna. Sjeme graška rijetko pokazuje znakove dormantnosti, iako ponekad svježe požeto sjeme sporo klije (Black i sur., 2006.).

Tvrda sjemena ljuska je nasljedna osobina kod mahunarki, ali je ujedno povezana s klimatskim faktorima te ovisi o stupnju dehidracije (Argel i Paton, 1999.). Ladizinsky (1987.) je utvrdio da je kod divljih mahunarki, posebno kod leće, vrlo nizak postotak klijanja pa stoga nije moguć njihov uspješan uzgoj u kulturi. Nadalje, sjeme divljeg graška nepropusno je za vodu (Ladizinsky, 1989.), odnosno dormantno godinu ili više dana (Weeden, 2007.) te ga je potrebno skarificirati. U istraživanju su Penã-Valdivia i sur. (2002.) utvrdili da prekidanje dormantnosti visokim temperaturama ima pozitivan učinak na divlje tipove graha, ali ne i na sjeme udomaćenih tipova.

Kod krmnih mahunarki je ispitivana učinkovitost rezličitih metoda na prekid dormantnosti. Metode skarifikacije (tretmani s visokom temperaturom, smrzavanje, mehaničke metode i tretmani s kiselinama) su pokazale značajnu važnost za prekid dormantnosti te poboljšanje klijavosti, a svaku je metodu potrebno prilagoditi vrsti (Kimura i Islam, 2012.). Sjeme crvene djeteline ima visoki stupanj klijavosti nakon skarifikacije i hladnog tretmana (Van Assche i sur., 2003.). Asci i sur. (2011.) su također utvrdili da je postotak klijanja crvene djeteline nakon skarifikacije $(54,2 \%)$ znatno viši nego u kontroli $(29,4 \%)$. Brzina klijanja je bila veća pri tretmanima prethodnog hlađenja (5 dana na $4{ }^{\circ} \mathrm{C}$ ), prethodnog grijanja ( 45 minuta u vodi na $60{ }^{\circ} \mathrm{C}$ ), u tretmanu s ključalom vodom u odnosu na kontrolu i tretman $\mathrm{KNO}_{3}$. Tiryaki i Topu (2014.) su razvili novu metodu za suzbijanje dormantnosti koja je uzrokovana tvrdom sjemenom ljuskom kod mahunarki. Sjeme bijele lupine i crvene djeteline su podvrgli tretmanu smrzavanja na $-80^{\circ} \mathrm{C}$ te su sjemenke odmah nakon toga bile uronjene 5 sekundi u vodu na $90{ }^{\circ} \mathrm{C}$. Rezultat je bio znatno veći postotak klijavosti u odnosu na kontrolu (kod bijele lupine 84,16\%:3,3\%, a kod crvene djeteline 74,5\%:26,0\%). Kandil i sur. (2012.) su utvrdili da su dva tretmana stratifikacije (2 sata na $-80{ }^{\circ} \mathrm{C}$ i 5 sati na $80{ }^{\circ} \mathrm{C}$ ) u kombinaciji sa skarifikacijom brusnim papirom reducirali postotak tvrde sjemene ljuske kod lucerne za 70,45\% i $63,64 \%$ u odnosu na kontrolu dok je izloženost sjemena lucerne hladnom tretmanu stratifikacije $\left(5\right.$ sati na $\left.-5^{\circ} \mathrm{C}\right)$ značajno utjecala na klijanje sjemena. 


\section{ZAKLJUČAK}

U Hrvatskoj se proizvode najčešće tradicijski kultivari zrnatih mahunarki koji su prilagođeni specifičnoj klimatskoj i reljefnoj raznolikosti Hrvatske. Zrnate mahunarke uzgajaju mali poljoprivredni proizvođači na obiteljskim gospodarstvima, a koriste se za ljudsku prehranu i za hranidbu stoke dok se krmne mahunarke koriste isključivo za ishranu stoke. Klijanje i dormantnost sjemena izuzetno su važni u poljoprivrednoj proizvodnji, a pod utjecajem su gena i biljnih hormona te ovise o kakvoći sjemena i okolišnim čimbenicima (voda, temperatura, kisik, svjetlost, zaslanjenost i pH tla). Klijanje je ključna faza za razvoj nove biljke, a samim time i za biljnu proizvodnju jer kvaliteta usjeva ovisi o interakciji između okolišnih čimbenika i kvalitete sjemena.

Dormantnost sjemena je jako važna osobina jer osigurava opstanak biljke (vrste) tijekom nepovoljnih vremenskih uvjeta, što se posebno odnosi na divlje vrste. Stupanj dormantnosti je nasljedan.

Klijanje sjemena mahunarki može biti onemogućeno zbog debljine sjemene ljuske jer sjeme ne može usvojiti vodu i plinove. Ova osobina je danas tipična za divlje tipove zrnatih mahunarki te za krmne mahunarke. Tijekom udomaćenja i procesom oplemenjivanja je kod zrnatih mahunarki dormantnost izgubljena te one kliju čim dođu u povoljne okolišne uvjete. Za krmne mahunarke je potrebno koristiti neki od tretmana skarifikacije ili stratifikacije (ovisno o vrsti) kako bi se prekinula dormantnost te pospješilo klijanje.

U poljoprivrednoj proizvodnji Hrvatske zrnate mahunarke su nedovoljno zastupljene. Pregled i usporedba literaturnih podataka ukazuju na njihov velik potencijal s obzirom na njihova prehrambena svojstva, a zbog gubitka dormantnosti tijekom udomaćenja nisu potrebni nikakvi tretmani prije same sjetve. Odabirom pogodnih kultivara i pravilnom agrotehnikom, tradicijski kultivari zrnatih mahunarki mogu se uzgajati na puno većim površinama. 


\section{LITERATURA}

1. Al-Ani A, Bruzau F, Raymond P, Saint-Ges V, Leblanc JM, Pradet A (1985): Germination, respiration, and adenylate energy charge of seeds at various oxygen partial pressures. Plant Physiol 79(3): 885-90

2. Al-Karaki GN (1998): Seed size and water potential effects on water uptake, germination and growth of lentil. J Agronomy Crop Sci 181: 237-242

3. Ambika S, Manonmani V, Somasundaram G (2014): Review on Effect of Seed Size on Seedling Vigour and Seed Yield. Research Journal of Seed Science 7: 3138

4. Argel PJ, Paton CJ (1999): Overcoming legume hardseededness. U: Forage Seed production: Tropical and Sub-Tropical Species (Loch DS, Ferguson JE, ur.). CABI Publishing, NewYork 2: 247-266

5. Asci OO, Acar Z, Ayan I, Basaran U, Mut H (2011): Effect of pretreatments on seed germination rate of red clover (Trifolium pratense L.) populations. Afr J Agric Res 6 (13): 3055-3060

6. Baskin JM, Baskin CC (2004): A classification system for seed dormancy. Seed Sci Res 14: 1-16

7. Bewley JD (1997): Seed germination and Dormancy. Plant Cell 9:1055-1066

8. Black JM, Bewley JD, Halmer P (2006): The Encyclopedia of Seeds: Science, Technology and Uses. CAB International. Cambridge, USA

9. Boye J, Zare F, Pletch A (2010): Pulse proteins: Processing, characterization, functional properties and applications in food and feed. Food Res Int 43: 414-431

10. Bradford KJ, Come D, Corbineau F (2007): Quantifying the oxygen sensitivity of seed germination using a population-based threshold model. Seed Sci Res 17: 3343

11. Brar GS, Gomez JF, McMichael BL, Matches AG, Taylor HM (1991): Germination of Twenty Forage Legumes as Influenced by Temperature. Agron J 83:173-175

12. Bukvić G, Grljušić S, Liška A, Antunović M, Kiš D, Bukvić A (2007): Klijavost sjemena soje i krmnog graška u zavisnosti od ph vrijednosti vodene otopine. Sjemenarstvo 24 (2): 73-84

13. Bukvić G, Grljušić S, Rozman V, Liška A, Lović I (2008): Utjecaj pH i temperature na energiju klijanja, klijavost, dužinu korijena i hipokotila klijanaca različitih kultivara lucerne (Medicago sativa L.). Agriculture 14 (1): 9-14

14. Bukvić G, Grljušić S, Josipović A, Greger Ž, Marijanović M, Bilušić Lj (2009): Klijanje sjemena crvene djeteline (cv. Viola) u zavisnosti o $\mathrm{pH}$ vrijednosti vodene otopine i starosti sjemena. Poljoprivreda (Osijek) 15 (1): 23-27 
15. Chaturvedi SK, Gupta S, Rashmi J (2011): Biology of food legumes. U: Biology and breeding of food legumes (Pratap A, Kumar J, ur.), CABI International, Chambridge 35-48

16. Cokkizgin A (2012): Salinity Stress in Common Bean (Phaseolus vulgaris L.) Seed Germination. Not Bot Horti Agrobo 40 (1): 177-182

17. Čupić T, Gantner R, Popović S, Tucak M, Sudar R, Stjepanović M (2012): Rasprostranjenost jednogodišnjih mahunarki u Hrvatskoj. U: Proceedings \& abstracts of the 5th international scientific/professional conference Agriculture in nature and environment protection (Stipešević B, Sorić R, ur.), Glas Slavonije d.d., Osijek: 220-225

18. De Ron AM (2015): Grain legumes. Springer Science+Business Media, New York

19. Dujmović-Purgar D, Koraca K, Bertoša J, Bolarić S (2009): Rasprostranjenost crvene djeteline (Trifolium pratense L.) u Hrvatskoj. Agronomski Glasnik 3: 225236

20. Eira MTS, Caldas LS (2000): Seed dormancy and germination as concurrent processes. R Bras Fisiol Veg 12: 85-104

21. Ellis RH, Hong TD (2006): Temperature Sensitivity of the Low-moisture-content Limit to Negative Seed Longevity-Moisture Content Relationships in Hermetic Storage. Ann Bot 97: 785-791

22. Fenner M, Thompson K (2005): The Ecology of Seeds, 2nd ed, Cambridge University Press, Cambridge, UK

23. Finch-Savage WE, Leubner-Metzger G (2006): Seed dormancy and the control of germination. New Phyto 171: 501-523

24. Finch-Savage WE, Bassel GW (2015): Seed vigour and crop establishment: extending performance beyond adaptation. J Exp Bot 67 (3): 567-591

25. Finkelstein R, Reeves W, Ariizumi T, Steber C (2008): Molecular Aspects of Seed Dormancy. Annu Rev Plant Biol 59: 387-415

26. Frankland B, Taylorson R (1983): Light Control of Seed Germination. U: Encyclopedia of Plant Physiology: Photomorphogenesis (Shropshire W Jr., Mohr H, ur.). Springer-Verlag Berlin Heidelberg, New York 16 A: 428-456

27. Fuller DQ, Allaby R (2009): Seed Dispersal and Crop Domestication: Shattering, Germination and Seasonality in Evolution under Cultivation. Annual Plant Reviews 38: 238-295

28. Gatarić Đ, Radić V, Đurić B, Kovačević Z, Lakić Ž (2009): Morfološko-biološke osobine sjemena eko-tipa graha poljaka (Lathirus sativus L.) iz Petrovog polja. Agroznanje 10 (2): 31-38 
D. Saraf i sur.: Klijanje i dormantnost kod mahunarki

29. Ghaderi-Far F, Gherekhloo J, Alimagham M (2010): Influence of environmental factors on seed germination and seedling emergence of yellow sweet clover (Melilotus officinalis). Planta Daninha, Viçosa-MG 28 (3): 463-469

30. Gresta F, Avola G, Onofri A, Anastasi U, Cristaudo A (2011): When Does Hard Coat Impose Dormancy in Legume Seeds? Lotus and Scorpiurus Case Study. Crop Sci 51: 1739-1747

31. Grljušić S, Bukvić G, Vratarić M, Antunović M, Sudarić A, Prepelac I (2007): Utjecaj pH vodene otopine na klijavost sjemena soje. Agriculture 13 (2): 5-9

32. Gubler F, Millar AA, Jacobsen JV (2005): Dormancy release, ABA and preharvest sprouting. Curr Opin Plant Biol 8(2): 183-187

33. Haramija J (2007): Utjecaj kvalitete sjemena graha mahunara na klijavost te rast $\mathrm{i}$ razvoj klice. Sjemenarstvo 24 (2): 97-110

34. Hartmann HT, Kester DE, Davies FT (1990): Plant Propagation: Principles and Practices, 5th ed. Prentice-Hall, Englewood Cliffs, New Jersey

35. ISTA Germination Committee (2006): Handbook on Seedling Evaluation (Don R, ur.), 3rd Edition, International Seed Testing Association, Switzerland

36. ISTA (2009): International Rules for Seed Testing. International Seed Testing Association, Switzerland

37. Jevtić S, Šuput M, Gotlin J, Pucarić A, Miletić N, Klimov S, Đorđevski J, Španring J, Vasilevski G (1986): Posebno ratarstvo 1. Naučna knjiga, Beograd

38. Kandil AA, Sharief AE, Odam AMA (2012): Dormancy overcoming of some alfalfa varieties. Research Journal of Seed Science 5: 19-31

39. Kaymakanova M (2009): Effect of Salinity on Germination and Seed Physiology in Bean (Phaseolus Vulgaris L.). Biotechnol Biotechnol Equip 23(1): 326-329

40. Khajeh-Hosseini M, Powell AA, Bingham IJ (2003): The interaction between salinity stress and seed vigour during germination of soyabean seeds. Seed Sci Technol 31: 715-725

41. Kigel J, Rosental L, Fait A (2015): Seed Physiology and Germination of Grain Legumes. U: Grain legumes (De Ron AM, ur.). Springer Science+Business Media, New York 10: 327-363

42. Kimura E, Islam MA (2012): Seed Scarification Methods and their Use in Forage Legumes. Research Journal of Seed Science 5 (2): 38-50

43. Koornneef M, Bentsink L, Hilhorst H (2002): Seed dormancy and germination. Curr Opi Plant Biol 5: 33-36

44. Kucera B, Cohn MA, Leubner-Metzger G (2005): Plant hormone interactions during seed dormancy release and germination. Seed Sci Res 15: 281-307

45. Ladizinsky G (1987): Pulse domestication before cultivation. Econ Bot 41: 60-65 
D. Saraf i sur.: Klijanje i dormantnost kod mahunarki

46. Ladizinsky $G$ (1989): Origin and domestication of the southwest asian grain legumes. U: Foraging and Farming: The Evolution of Plant Exploitation (Harris DR, Hillman GC, ur.). Unwin Hyman, London 31: 374-388

47. Lešić R, Borošić J, Buturac I, Herak Ćustić M, Poljak M, Romić D (2004): Povrćarstvo, 2. izdanje, Zrinski d. d., Čakovec

48. Leto J (2013): Važnost sitnozrnih mahunarka u proizvodnji krme. U: Zbornik radova: Petnaesto savjetovanje uzgajivača ovaca i koza u Republici Hrvatskoj i Četrnaesta izložba hrvatskih ovčjih i kozjih sireva (Mulc D, ur.), Hrvatska poljoprivredna agencija, „ZEBRA“ - tiskarski obrt, Vinkovci, 52-61

49. Li R, Shi F, Fukuda K, Yang Y (2010): Effects of salt and alkali stresses on germination, growth, photosynthesis and ion accumulation in alfalfa (Medicago sativa L.). J. Soil Sci. Plant Nutr. 56: 725-733

50. Machado Neto NB, Prioli MR, Gatti AB, Mendes Cardoso VJ (2006): Temperature effects on seed germination in races of common beans (Phaseolus vulgaris L.). Acta Sci Agron 28 (2): 155-164

51. Milberg P, Andersson L., Thompson K (2000): Large-seeded spices are less dependent on light for germination than small-seeded ones. Seed Sci Res 10: 99104

52. Miransari M, Smith DL (2014): Plant hormones and seed germination. Environ Exp Bot 99: 110-121

53. Morel MA, Brańa V, Castro-Sowinski S (2012): Legume Crops, Importance and Use of Bacterial Inoculation to Increase Production. U: Crop Plant (Goyal A, ur.). InTech, Rijeka, Croatia, 217-240

54. Nikolaeva MG (1977): Factors controlling the seed dormancy pattern. U: The Physiology and Biochemistry of Seed Dormancy and Germination (Khan AA, ur.). North Holland Publishing, Amsterdam 51-74

55. Noodén LD, Blakley KA, Grzybowski JM (1985): Control of Seed Coat Thickness and Permeability in Soybean. Plant Physiol 79: 543-545

56. Nonogaki H, Bassel GW, Bewley JD (2010): Germination - Still a mystery. Plant Sci 179: 574-581

57. Nonogaki H (2014): Seed dormancy and germination - emerging mechanisms and new hypotheses. Front Plant Sci 5: 233

58. Okçu G, Kaya MD, Atak M (2005): Effects of Salt and Drought Stresses on Germination and Seedling Growth of Pea (Pisum sativum L.). Turk J Agric For 29: 237-242

59. Ozimec R, Karoglan Kontić J, Maletić E, Matotan Z, Strikić F (2015): Tradicijske sorte i Pasmine Dalmacije. Tiskara Zelina d.d., Sv. Ivan Zelina 
60. Penã-Valdivia CB, Garcia NR, Aguirre RJR, Trejo C (2002): The effects of high temperatures on dormancy and hypocotil-root growth of wild common bean (Phaseolus vulgaris L.). Seed Sci and Technol 30 (2): 231-248

61. Ranogajec Lj, Kanisek J, Deže J (2014): Ekonomski rezultati proizvodnje soje u Hrvatskoj. Zbornik radova: 49. hrvatski i 9. međunarodni simpozij agronoma (Marić S, Lončarić Z, ur.), Dubrovnik, Hrvatska

62. Seo M, Nambara E, Choi G, Yamaguchi S (2009): Interaction of light and hormone signals in germinating seeds. Plant Mol Biol 69: 463-472

63. Shaban M (2013): Effect of water and temperature on seed germination and emergence as a seed. IJABBR 1 (12): 1686-1691

64. Shu K, Meng YJ, Shuai HW, Liu WG, Du JB, Liu J, Yang WY (2015): Dormancy and germination: How does the crop seed decide? Plant Biol 17: 1104-1112

65. Sinck M, Bilgili U, Uzun A, Acikgoz E (2004): Effect of low temperatures on the germination different field pea genotypes. Seed Sci Technol, 32 (2):331-339

66. Smýkal P, Vernoud V, Blair MW, Soukup A, Thompson RD (2014): The role of the testa during development and in establishment of dormancy of the legume seed. Frontiers Plant Sci 5: 351

67. Statistički ljetopis Republike Hrvatske (2016): Državi zavod za statistiku, Zagreb. On Line URL: http://www.dzs.hr/Hrv_Eng/ljetopis/2015/sljh2015.pdf. (Pristupljeno 10.04.2016.)

68. Święcicki W, Kroc M, Kamel KA (2015): Lupins. U: Grain legumes (De Ron AM, ur.). Springer Science+Business Media, New York 10: 327-363

69. Tiryaki I, Topu M (2014): A Novel Method to Overcome Coat-Imposed Seed Dormancy in Lupinus albus L. and Trifolium pratense L. J Bot (2014): Article ID 647469

70. Tsegay BA, Gebreslassie B (2014): The effect of salinity $(\mathrm{NaCl})$ on germination and early seedling growth of Lathyrus sativus and Pisum sativm var. abyssinicum. Afr J Plant Sci 8(5): 225-231

71. Undersander D, Hall MH, Vassalotti P, Cosgrove D (2011): Alfalfa germination and growth. University of Wisconsin Cooperative Extension, R-08-2011, Madison

72. Van Assche JA, Debucquoy KLA, Rommens WAF (2003): Seasonal cycles in the germination capacity of buried seeds of some Leguminosae (Fabaceae). New Phytol 158: 315-323

73. Van Gastel AGJ, Bishaw Z, Niane AA, Gregg BR, Gan Y (2007): Chickpea Seed Production. U: Chichpea breeding and management (Yadav SS, Redden R, Chen W, Sharma B, ur.), CABI Publishing 417-444 
74. Wang YR, Hanson J, Mariam YW (2007): Effect of sulfuric acid pretreatment on breaking hard seed dormancy in diverse accessions of five wild Vigna species. Seed Sci Tech 35: 550-559

75. Weeden NF (2007): Genetic changes accompanying the domestication of Pisum sativum: is there a common genetic basis to the 'domestication syndrome' for legumes? Ann Bot 100: 1017-1025

Adresa autora - Authors address:

Dragan Saraf, mag.ing.agr.,

Monika Vidak, mag.ing.agr;

e-mail: mvidak@agr.hr,

Doc.dr.sc. Martina Grdiša,

Doc.dr.sc. Klaudija Carović-Stanko,

Sveučilište u Zagrebu, Agronomski fakultet, Zavod za sjemenarstvo

Svetošimunska cesta 25,

10000 Zagreb 